\title{
Penerapan Pencatatan dan Laporan Akuntansi Pada Usaha Mikro Kecil dan Menengah (UMKM)
}

\author{
Ade Sri Mulyani ${ }^{1}$ \\ Universitas Bina Sarana Informatika, ade.aml@bsi.ac.id \\ Ety Nurhayaty ${ }^{2}$ \\ Universitas Bina Sarana Informatika, ety.eyy@bsi.ac.id \\ Kasmanto Miharja ${ }^{3}$ \\ Universitas Bina Sarana Informatika, Kasmanto.kmm@bsi.ac.id
}

\begin{abstract}
Abstrak
Usaha Mikro, Kecil dan Menengah (UMKM) merupakan salah satu penggerak perekonomian suatu negara dalam meningkatkan kesejahteraan masyarakat dan mempunyai potensi yang besar jika dikelola dan dikembangkan dengan baik. Usaha Mikro, Kecil dan Menengah (UMKM) mampu memberikan kontribusi bagi perekonomian nasional, khususnya dalam menyediakan kesempatan kerja dan merupakan sumber yang cukup besar bagi penerimaan Negara.(Putriyandari, 2019). Walaupun mempunyai kontribusi yang besar, kenyataan menunjukan bahwa Usaha Mikro, Kecil dan Menengah (UMKM) masih belum dapat mewujudkan kemampuannya secara maksimal, dikarenakan masih kurangnya pengetahuan dari para pelaku usaha dalam melakukan penerapan akuntansi dalam mengelola hasil usaha, jika akuntansi dilakukan secara baik, maka para pelaku usaha dapat mengambil keputusan dalam menjalankan usaha sesuai dengan data yang akurat, bukan berdasarkan pengalaman dan ingatan saja. Penelitian ini bertujuan untuk mengetahui seberapa jauh Usaha Mikro, Kecil dan Menengah (UMKM) menerapkan pencatatan dan pelaporan akuntansi yang dapat digunakan sebagai alat untuk menilai kinerja usaha. Metode pengumpulan data dalam penelitian ini menggunakan metode observasi dengan kuisioner dan wawancara langsung dengan responden. Penelitian ini menggunakan teknik analisis dekriptif kualitatif. Hasil penelitian menunjukan bahwa Usaha Mikro, Kecil dan Menengah (UMKM) masih belum banyak yang menerapkan akuntansi sesuai dengan siklus akuntansi, para pelaku usaha baru melakukan tahap awal dari akuntansi seperti mengumpulkan bukti transaksi dan mencatat transaksi yang terjadi. Kendala yang dihadapi oleh para pelaku usaha adalah masih kurangnnya pengetahuan dan kesadaran yang dimiliki para pelaku usaha untuk melakukan pencatatan dan pelaporan akuntansi, para pelaku usaha beranggapan bahwa hanya dengan melakukan pengumpulan bukti transaksi dan pencatatan transaksi yang terjadi mereka sudah dapat menentukan laba, tanpa perlu membuat laporan keuangan, karena menurut para pelaku usaha membuat laporan keuangan memerlukan biaya yang cukup bear dan waktu yang lama.
\end{abstract}

Kata Kunci: Usaha Mikro Kecil dan Menengah (UMKM), Akuntansi, Laporan Keuangan, 
Jurnal Pengabdian Kepada Masyarakat

\begin{abstract}
Micro, Small and Medium Enterprises (MSMEs) are one of the drivers of the economy, despite having a large contribution, the fact shows that Micro, Small and Medium Enterprises still have not been able to realize their capabilities to the maximum, due to the lack of knowledge from business people in doing the application of accounting in managing business results, if accounting is carried out properly, then business actors can make decisions in conducting business in accordance with accurate data, not based on experience and memory. This study aims to determine the extent to which Micro, Small and Medium Enterprises (MSMEs) apply accounting recording and reporting that can be used as a tool to assess business performance. The method of data collection in this study used the observation method with questionnaires and direct interviews with respondents. This study uses qualitative descriptive analysis techniques. The results of the study show that there are not many Micro, Small and Medium Enterprises (MSMEs) that apply accounting in accordance with the accounting cycle, new business actors carry out the initial stages of accounting such as collecting transaction evidence and recording transactions that occur. The constraints faced by business actors are the lack of knowledge and awareness possessed by business actors to carry out accounting recording and reporting, business people assume that only by collecting transaction evidence and recording transactions that occur can they determine profits, without the need to make financial statements, because according to business people making financial statements requires considerable costs and a long time.
\end{abstract}

Keyword : Micro, Small and Medium Enterprises (MSMEs), Accounting, Financial Statements.

\title{
Pendahuluan
}

Usaha Mikro, kecil dan Menengah (UMKM) di Indonesia merupakan penggerak perekonomian dan mempunyai peranan yang sangat penting. Walaupun berkontribusi besar, kenyataan menunjukan bahwa Usaha Kecil Mikro dan Menengah (UMKM) masih belum dapat mewujudkan kemampuan dan peranannya secara maksimal dalam perekonomian, dikarenakan Usaha Mikro Kecil dan Menengah (UMKM) masih memiliki hambatan dan kendala baik bersifat internal maupun eksternal terutama dalam membuat laporan keuangan. Banyak para pelaku mengelola usahanya dengan dasar kemapuan yang kurang memadai terutama aspek pengelolaan keuangan tanpa memiliki dasar pengetahun maupun keterampilan mengenai manajemen usaha dan manajemen keuangan yang baik. Aspek-aspek manajemen usaha yang meliputi perencanaan usaha, pengorganisasian, implementasi dan pengendalian usaha menjadi sesuatu yang jarang diperhatikan. Padahal itu merupakan aspek yang sangat penting dalam membangun dan mengembangkan usaha karena kelanjutan usaha dinilai dari tolak ukur kinerja keuangannya. Sebagian besar pelaku usaha mikro kecil dan menengah tidak mengetahui laba yang didapatkan, mereka menjawab bukan dengan nominal angka rupiah melainkan dengan benda-benda berwujud seperti peralatan untuk usaha, motor, mobil dan rumah. Jawaban tersebut tidak menggambarkan laba yang sebenarnya didapat oleh perusahaan karena itu merupakan salah satu penggunaan dana yang mungkin didanai dari laba atau dari utang ataupun dari modal pemilik. Untuk mengelola keuangan dengan baik adalah dengan cara menerapkan akuntansi 
dengan baik. Dengan akuntansi yang memadai dapat memenuhi persyaratan dalam pengajuan kredit berupa laporan keuangan, mengevaluasi kinerja , mengetahui posisi keuangan dan menghitung pajak. (Warsono,2010).

Melihat pentingnya penerapan akuntansi bagi Usaha Kecil Mikro dan Menengah, IAI selaku organisasi profesi sekaligus sebagai badan penyusun Standar Akuntansi Keuangan (SAK) melalui dewan standar Akuntansi (DSAK) menyusun standar akuntansi yang sesuai dengan karakteristik Usaha Mikro Kecil dan Menegah (UMKM) pada tahun 2009, DSAK telah mengesahkan SAK ETAP ( Entitas tanpa Akuntabilitas Publik) dan standar ini berlaku efektif per 1 Januari 2011. SAK ETAP merupakan Standar akuntansi untuk entitas yang tidak memiliki akuntabilitas kepada publik, standar ini masih dirasa sulit untuk diterapkan oleh Usaha Mikro Kecil dan Menengah sehingga IAI menyiapkan Standar Akuntansi Keuangan Entitas Mikro, Kecil dan Menengah (SAK EMKM) dan telah disahkan pada tanggal 24 oktober 2016. SAK ETAP bertujuan untuk digunakan entitas tanpa akuntabilitas publik. Entitas tanpa akuntabilitas pubik adalah entitas yang : (a) tidak memiliki akuntabilitas publik signifikan; dan (b) laporan keuangan untuk tujuan umum bagi pengguna eksternal (general purpose financial statement). Pengguna eksternal adalah pemilik yang tidak terlibat langsung dalam pengelolaan usaha kreditur dan lembaga pemeringkat kredit (Standar keuangan entitas tanpa akuntabilitas Publik : 2009).

Setiap kegiatan bisnis tentunya memerlukan pencatatan transaksi agar setiap transaksi yang terjadi bisa diketahui secara jelas. Laporan keuangan masih diyakini sebagai alat yang handal bagi para pemakainya, untuk mengurangi resiko ketidakpastian dalam pengambilan keputusan-keputusan ekonomi. Informasi Akuntansi dalam bentuk laporan keuangan banyak memberikan manfaat dan sangat diperlukan oleh pihak manajemen perusahaan dalam merumuskan berbagai keputusan dan memecahkan segala permasalahan yang dihadapi oleh Usaha Mikro Kecil dan Menengah (UMKM). Dengan diterapkannya akuntansi dalam bentuk laporan keuangan Usaha Mikro Kecil dan Menengah (UMKM) dapat memperoleh informasi tentang kinerja, aliran kas dan informasi yang lain yang berkaitan dengan laporan keuangan. Sehingga setiap keputusan yang diambil oleh pemilik dalam mengembangkan usahanya akan didasari dengan kondisi keuangan yang dilaporkan secara lengkap.

\section{Akuntansi}

Akuntansi merupakan proses identifikasi pencatatan dan pelaporan seluruh transaksi atau kejadian ekonomi yang terjadi dalam suatu perusahaan. (Yulius, 2011). Laporan keuangan dalam standar akuntansi keuangan terdiri 5 (lima) yaitu : Neraca, laporan laba-rugi, laporan perubahan modal laporan arus kas dan catatan atas laporan keuangan.(Ikatan Akuntan Indonesia, 2000) Laporan-laporan tersebut mempunyai fungsi yang berbeda-beda yang berguna untuk memberikan informasi posisi usaha atau bisnis. Laporan laba rugi adalah suatu ihktisar pendapatan dan beban selama periode tertentu, misal sebulan atau setahun. Laporan Perubahan modal suatu ikhtisar mengenai perubahan pada modal pemilik yang telah terjadi selama periode waktu tertentu seperti pada bulanan maupun tahunan. Laporan ini dibuat setelah laporan laba rugi karena laporan laba rugi ikut muncul pada laporan 
ini. (Warren, 2006). Laporan Perubahan modal suatu ikhtisar mengenai perubahan pada modal pemilik yang telah terjadi selama periode waktu tertentu seperti pada bulanan maupun tahunan. Laporan ini dibuat setelah laporan laba rugi karena laporan laba rugi ikut muncul pada laporan ini. (Warren, 2006). Neraca merupakan sebuah laporan yang berisi daftar mengenai aset, kewajiban, dan modal pemilik pada tanggal tertentu. Pada umumnya tanggal pada neraca menggunakan hari pada akhir bulan atau akhir tahun. (Warren, 2006). Laporan aru kas adalah suatu laporan tentang aktivitas penerimaan dan pengeluaran kas perusahaan selama suatu periode tertentu. (Rudianto, 2012). Laporan arus kas digunakan oleh manajemen untuk mengevaluasi kegiatan operasional yang telah berlangsung dan merencanakan aktivitas investasi dalam pembiayaan dimasa yang akan datang. (Hery, 2015)

Peran Akuntansi Bagi Usaha Mikro, Kecil dan Menengah (UMKM)

Akuntansi mempunyai peranan penting untuk mencapai keberhasilan usaha, termasuk bagi Usaha Mikro, Kecil dan Menengah (UMKM) dan informasi akuntansi dapat menjadi dasar yang andal bagi pengambilan keputusan dalam pengelolaan usaha kecil dan menengah. Penyediaan informasi akuntansi bagi usaha kecil dan menengah juga diperlukan khususnya untuk akses subsidi pemerintah dan akses tambahan modal bagi Usaha Mikro, Kecil dan Menengah (UMKM) telah diatur dalam Undang-Undang Republik Indonesia No. 20 tahun 2008 Tentang Usaha Mikro, Kecil dan Menengah. Laporan keuangan Usaha Mikro Kecil dan Menengah (UMKM) adalah pembukuan sederhana yang dibuat oleh pemilik Usaha untuk mengetahui apakah bisnis yang dikelola menguntungkan atau merugikan. Penerapan akuntansi mempunyai peranan yang sangat penting dalam mengembangkan Usaha Mikro Kecil dan Menengah, tanpa adanya laporan keuangan para pelaku usaha tidak dapat mengetahui secara persis berapa pendapatan, pengeluaran dan berapa laba usaha. Kalaupun ada perncenaan biasanya tidak tersusun secara rapi dan tertib. Permasalah ini semakin kompleks seiring dengan bertambah besarnya kegiatan usaha. Dalam menyusun laporan keuangan sebaiknya Usaha Mikro, Kecil dan Menengah (UMKM) harus disiplin dalam melakukan pencatatan setiap transaksi dalam jurnal atau laporan keuangan, lalu mendokumentasikan setiap bukti-bukti transaksi sehingga mempermudah dalam proses pencatatan keuangan. (Widjaja, 2019)

\section{Metode}

Data yang digunakan dalam penelitian ini adalah dengan menggunakan data primer yang berbentuk Wawancara/interview dan kuisioner terhadap pemilik atau pengelola toko. Analisis yang digunakan dalam penelitian ini penulis menggunakan analisis deskriptif. Tujuan analisis deskriptif yaitu untuk memberikan gambaran mengenai hasil penelitian secara umum profil responden, sikap wirausaha dan peningkatan usaha dipandang dari sudut responden dalam melihat tentang Penerapan Akuntansi bagi UsahaMikro, Kecil dan Menengah. Penelitian ini menggunakan pendekatan deskriptif dengan melakukan wawancara kepada para pelaku Usaha Mikro Kecil dan Menengah (UMKM), dari hasil wawancara tersebut kemudian penulis menganalisis hasil wawancara para pelaku usaha untuk melihat 
bagaimana persepsi pelaku usaha tentang penerapan akuntansi. Tipe penelitian deskriptif bertugas untuk melakukan representasi obyektif mengenai gejala-gejala yang terdapat di dalam masalah penelitian. Representasi itu dilakukan dengan mendeskripsikan gejala-gejala sebagai data atau fakta sebagaimana adanya (Bungin, 2003).

\section{Hasil dan Pembahasan}

Penelitian diambil dari beberapa sampel yang dijadikan sumber penelitian, objek dalam penelitian ini adalah toko yang ada dijalan Kemang Raya Depok yang memenuhi kriteria sebagai Usaha Mikro Kecil dan Mengah (UMKM) sesuai dengan Undang-Undang No. 20 tahun 2008, dari 40 Responden yang disurvei ada 5 orang yang menolak diwawancara sehingga jumlah responden yang diperoleh peneliti adalah sebanyak 35 responen yang datanya diteliti lebih lanjut. Berikut merupakan hasil analisis kuisioner penelitian yang diketahui isajikan dalam bentuk tabel.

Bukti transaksi

Bukti transaksi merupakan proses komunikasi dalam perusahaan dan membantu dalam proses pembuatan laporan keuangan, yang termasuk bukti transaksi adalah struk atau nota penjualan, kwitansi, faktur penjualan, faktur pembelian, nota pengirimanan nota penerimaan barang. Pelaku usaha ada yang memiliki bukti transaksi ada yang tidak memiliki bukti transaksi, mereka yang tidak memilik bukti transaksi biasanya meriksa lalu membuang atau tidak menyimpan dengan baik setiap bukti transaksi yang mereka buat atau terima. Dari tabel 1 dapat diketahui dari 35 responden, 28 memiliki bukti transaksi dan 7 responden tidak memiliki bukti transaksi, pemilik usaha menganggap mereka belum merasa terlalu penting untuk memiliki dan menyimpan bukti transaksi karena usaha mereka belum terlalu besar.

Table 1. Bukti Transaksi dari setiap transaksi usaha

\begin{tabular}{llcc}
\hline \multicolumn{4}{c}{ Bukti Transaksi Yang dimiliki } \\
\hline No. & \multicolumn{1}{c}{ Bukti Transaksi } & Jumlah & $\%$ \\
\hline 1 & Memiliki & 28 & 80 \\
2 & Tidak Memiliki & 7 & 20 \\
& Total & 35 & 100 \\
\hline
\end{tabular}

Sumber : Data primer yang diolah

Transaksi Yang Dicatat Oleh Pemilik Usaha

Untuk mengetahui apakah Usaha Mikro, Kecil dan Menengah melakukan pencatatan keuangan atau tidak perlu diketahui mengenai pencatatan apa saja yang dilakukan pengelola usaha. Berikut ini jumlah responden yang melakukan pencatatan berdasarkan pertanyaan yang diajukan: 
Jurnal Pengabdian Kepada Masyarakat

Tabel 2. Transaksi yang dicatat oleh pemilik usaha

\begin{tabular}{cccccccc}
\hline No. & $\begin{array}{c}\text { Tranaksi yang } \\
\text { dicatat }\end{array}$ & \multicolumn{3}{c}{$\begin{array}{c}\text { Responden } \\
\text { Mencatat } \\
\text { Jumlah }\end{array}$} & $\mathbf{\%}$ & $\begin{array}{c}\text { Tidak mencatat } \\
\text { Jumlah }\end{array}$ & $\begin{array}{c}\text { Jumlah } \\
\text { responden }\end{array}$ \\
\hline 1 & Penjualan & 30 & 86 & 5 & 14 & Total & \% \\
\hline 2 & Pembelian & 30 & 86 & 5 & 14 & 35 & 100 \\
3 & Persediaan & 27 & 77 & 8 & 23 & 35 & 100 \\
4 & Kas Masuk & 25 & 71 & 10 & 29 & 35 & 100 \\
5 & Kas Keluar & 23 & 66 & 12 & 34 & 35 & 100 \\
6 & Biaya & 21 & 60 & 14 & 40 & 35 & 100 \\
7 & Gaji & 17 & 49 & 18 & 51 & 35 & 100 \\
\hline
\end{tabular}

Sumber : data primer yang diolah

Dari tabel 1 menunjukan bahwa ada 30 responden yang melakukan pencatatan penjualan dan pembelian, menurut pengelola usaha mereka perlu mencatat pembelian dan penjualan untuk mengetahui berapa laba yang akan mereka peroleh yang mencatat persediaan 27 responden, pengelola usaha yang mencatat persedian dikarenakan untuk mengetahui stok yang mereka miliki, stok yang terjual dan stok yang telah habis. Responden yang tidak memiliki catatan persedian ada 8 responden pemilik usaha beranggapan mereka tidak perlu mencatat stok karena stok mereka tidak terlalu banyak dan mereka masih bisa mengingat stok apa saja yang telah habis. Pengelola yang mencatat kas masuk 25 responden dan kas keluar 23 responden, pengelola usaha mencatat kas masuk dan kas keluar untuk mengetahui berapa laba yang meraka dapatkan dari selisih kas masuk dan keluar, pengelola yang tidak mencatat kas masuk 10 responden dan yang tidak mencatat kas keluar 12 responden, pengelola usaha yang tidak mencatat kas masuk dan kas keluar beranggapan selisih fisik uang dari kas masuk dan kas keluar itu adalah laba yang mereka dapatkan. Ada 21 responden melakukan pencatatan biaya dan 17 responden yang mencatat gaji, pengelola usaha yang tidak mencatat biaya dan gaji beranggapan bahwa biaya dan gaji sudah dimasukkan didalam kas keluar.. Berdasarkan informasi dari tabel 3 bahwa sebagian besar pemilik usaha membuat laporan penjualan dan laporan pembelian, karena mereka beranggapan kegiatan mereka adalah memproduksi bahan mentah, membeli dan menjual.

Laporan Yang Dibuat Oleh Usaha Mikro, Kecil dan Menengah (UMKM)

Berdasarkan informasi dari tabel 3 menunjukkan bahwa sebagian besar pelaku Usaha Mikro, Kecil dan Menengah membuat laporan yang berfungsi untuk melihat aktivitas usaha mereka, hal ini dapat dilihat ada 29 responden yang membuat laporan pembelian, 27 reponden yang membuat laporan penjualan, untuk mengetahui berapa selisih dari penjualan dan pembelian mereka. 25 responden yang membuat laporan persediaan untuk mengetahui berapa stok yang terjual, stok yang masih tersedia dan stok yang sudah habis dan 13 responden yang membuat laporan gaji sebagai bahan untuk mengambil keputusan apakah perlu menambah karyawan atau mengurangi karyawan. 
Jurnal Pengabdian Kepada Masyarakat

Tabel 3. Laporan yang dibuat oleh pengelola usaha

\begin{tabular}{llcccccc}
\hline No. & $\begin{array}{c}\text { Laporan yang dibuat } \\
\text { responden }\end{array}$ & Membuat & \multicolumn{5}{c}{$\begin{array}{c}\text { Tidak } \\
\text { Membuat }\end{array}$} \\
\hline & & Jumlah & $\%$ & Jumlah & \% & Total & $\%$ \\
\hline 1 & Laporan pembelian & 29 & 83 & 6 & 17 & 35 & 100 \\
2 & Laporan penjualan & 27 & 77 & 8 & 23 & 35 & 100 \\
3 & Laporan persediaan & 25 & 71 & 10 & 29 & 35 & 100 \\
4 & Laporan gaji & 13 & 37 & 22 & 63 & 35 & 100 \\
\hline
\end{tabular}

Sumber : Data primer yang diolah

Laporan Keuangan Yang Dibuat Oleh Pengelolala Usaha Mikro, Kecil dan Menengah (UMKM)

Laporan keuangan merupakan hasil akhir dari suatu proses pencatatan yang merupakan suatu ringkasan dari transaksi keuangan yang terjadi selama satu tahun buku. Laporan keuangan yang lengkap meliputi laporan laba rugi, laporan perubahan modal, neraca, arus kas dan catatan atas laporan keuangan. Laporan keuangan bagi pelaku usaha masih dianggap belum terlalu penting dan mewah belum sebanding dengan kegunaannya, akibatnya pelaku usaha tidak tahu persis berapa pendapatan, pengeluaran, biaya dan laba mereka. Masalah tersebut akan semakin besar seiring bertambah majunya usaha mereka, sehingga mereka kesulitan menangani dan memantau usaha mereka terutama dalam mengambil keputusan, padahal dengan membuat laporan keuangan pengelola uaha dapat menganalisanya dan dapat mengambil keputusan dengan baik berdasarkan laporan keuangan. Dari tabel 4 diketahui bahwa 17 responden membuat laporan laba rugi, 9 responden membuat laporan perubahan modal, 6 responden membuat neraca dan 2 responden membuat arus kas. Pengelola Usaha berpikir membuat laporan merupakan hal yang sulit dan rumit selain itu membuat laporan keuangan memerlukan pengetahun dan waktu. Itulah alasan mereka tidak membuat laporan keuangan.

Tabel 4. Laporan Keuangan yang dibuat oleh pengelola UMKM

\begin{tabular}{llcccccc}
\hline No. & $\begin{array}{c}\text { Laporan } \\
\text { keuangan yang } \\
\text { dibuat responden }\end{array}$ & Membuat & & Membuat & & & \\
\hline & & Jumlah & $\%$ & Jumlah & $\%$ & Total & $\%$ \\
\hline 1 & Laporan Laba rugi & 17 & 49 & 18 & 51 & 35 & 100 \\
2 & Laporan & 9 & 26 & 26 & 74 & 35 & 100 \\
& Perubahan modal & & & & & & \\
3 & Neraca & 6 & 17 & 29 & 83 & 35 & 100 \\
4 & Arus Kas & 2 & 6 & 33 & 94 & 35 & 100 \\
\hline Sumber:
\end{tabular}

Sumber : Data primer yang diolah

Dasil hasil penelitian yang dilakukan, Usaha Mikro, Kecil dan Menengah (UMKM) yang menerapkan akuntansi adalah pengelola usaha yang sudah mulai berkembang, kesadaran mereka sudah mulai tumbuh ketika usaha mereka berkembang mereka memerlukan pencatatan akuntansi terutama ketika mereka melakukan pengajuan kredit untuk menambah modal usaha. Untuk Usaha Mikro, Kecil dan Menengah yang belum menerapkan akuntansi karena mereka merasa belum terlalu perlu untuk 
mencatat dan membuat laporan keuangan, transaksi mereka belum terlalu banyak dan tidak sesuai dengan manfaatnya. Ada beberapa faktor yang menyebabkan kurangnya kesadaran pelaku usaha untuk menerapkan akuntansi bahwa usaha yang mereka jalankan adalah usaha keluarga dan seringkali bercampur dengan keuangan pribadi, tidak adanya tenaga kerja yang ahli dalam akuntansi . Banyak Usaha Mikro, Kecil dan Menengah yang berhasil dan berjalan tanpa menerapkan akuntansi dalam mengambil keputusan hanya didasarkan pada kebiasaan yang berasal dari pengalaman. pelaku usaha dan hanya mengandalkan ingatan atas transaksi yang terjadi tanpa perlu melakukan pencatatan.

\section{Simpulan dan Rekomendasi}

Dari hasil penelitian diatas sebagian besar pelaku Usaha Mikro Kecil dan Menengah (UMKM) belum melakukan proses akuntansi secara lengkap, pelaku usaha menganggap bahwa akuntansi merupakan suatu yang sulit dan rumit yang memerlukan waktu dan biaya. Walaupun sebagian besar pelaku usaha belum merasa perlu menerapkan akuntansi tetapi mereka sudah melakukan tahap awal dalam proses akuntansi yaitu mereka sudah mulai mengumpulkan bukti transaksi dan melakukan pencatatan transaksi. Pelaku usaha masih mencampur catatan usaha dengan catatan keuangan pribadi, mereka menganggap semua yang diperoleh merupakan harta pribadi dan pengelola usaha merasa tanpa menerapkan akuntansi usaha mereka masih bisa berjalan dan berhasil, mereka melakukan pengambilan keputusan berdasarkan pengalaman.

\section{Daftar Pustaka}

Hery. 2015. Analisis Laporan Keuangan. CAPS. Yogyakarta.

Ikatan Akuntansi Indonesia. 2009. Standar Akuntansi Keuangan Entitas Tanpa Akuntabilitas Publik. Jakarta.

Putriyandari, R. Membangun Kepercayaan Investor dalam Penanaman Modal Perusahaan Konveksi Naga Putra Collection. Jurnal Abdimas, Vol. 2 No. 1 Februari 2019. Hal. 190-209

Undang-Undang Republik Indonesia Nomor 20 tahun 2008 tentang Usaha, Mikro Kecil dan Menengah.

Rudianto. 2012. Konsep Dan Teknik Penyusunan Laporan Keuangan. Jakarta: Erlangga.

Warren, Carl S., James Reeve dan Philip E. Fees. 2006. Pengantar Akuntansi, Edisi Dua Puluh Satu. Jakarta: Salemba Empat.

Warsono, Sony, Arif Darmawan, dan M.Arsyadi Ridha. 2010. Akuntansi UMKM Ternyata Mudah Dipahami dan Dipraktikkan. Yogyakarta: Asgard Chapter.

Widjaja, Y.R. 2018. Penyusunan Laporan Keuangan Sederhana Untuk UMKM Industri Konveksi. Jurnal Abdimas, Vol 1 No. 1 Februari 2018, Hal. 163-179. Yulius, H. 2011. 7 Langkah Pr aktis Membuat Pencatatan Akuntansi Keuangan Untuk perusahaan Jasa. Jakarta: Elex Media K omputindo. 